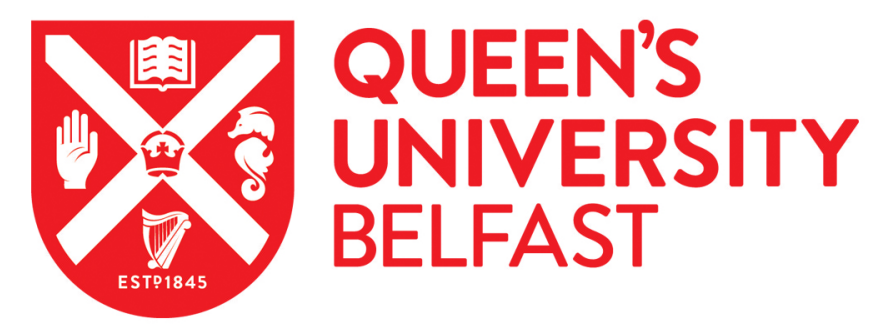

\title{
School's out forever: Postsecondary educational trajectories of students with autism
}

Dillenburger, K., Jordan, J-A., \& McKerr, L. (2016). School's out forever: Postsecondary educational trajectories of students with autism. Australian Psychologist, 51(4), 304-215. https://doi.org/10.1111/ap.12228

\section{Published in:}

Australian Psychologist

\section{Document Version:}

Peer reviewed version

\section{Queen's University Belfast - Research Portal:}

Link to publication record in Queen's University Belfast Research Portal

\section{Publisher rights}

(C) 2016 The Australian Psychological Society.

This work is made available online in accordance with the publisher's policies. Please refer to any applicable terms of use of the publisher.

\section{General rights}

Copyright for the publications made accessible via the Queen's University Belfast Research Portal is retained by the author(s) and / or other copyright owners and it is a condition of accessing these publications that users recognise and abide by the legal requirements associated with these rights.

Take down policy

The Research Portal is Queen's institutional repository that provides access to Queen's research output. Every effort has been made to ensure that content in the Research Portal does not infringe any person's rights, or applicable UK laws. If you discover content in the Research Portal that you believe breaches copyright or violates any law, please contact openaccess@qub.ac.uk. 


\title{
School's out forever: Postsecondary educational trajectories of
}

\author{
students with autism
}

\section{Accepted/in press Australian Psychologist (2016-04-20)}

Dillenburger, Karola, Jordan, Julie-Ann, \& McKerr, Lyn

\author{
Centre for Behaviour Analysis \\ School of Education \\ Queen's University Belfast
}

Research reported here was conducted as part of the BASE (Benchmarking Autism Services Efficacy) Project funded by the Office of the First and Deputy First Minister (OFMDFM). 
RUNNING HEAD: POSTSECONDARY EDUCATION OF STUDENTS WITH AUTISM

School's out forever: Postsecondary educational trajectories of students with autism

"What is already known about this topic"

1 - Autism prevalence has been rising.

2 - There has been little research focus on adults with autism.

3 - Adults with autism often have problems being fully included in society.

"What this topic adds"

1 - Adults with autism are well represented in Further and Higher Education Institutions.

2 - Adults with autism tend to experience lower levels of academic achievement than adults who do not have autism.

3 - Adults with autism tend to stay at home while they study.

\section{Abstract}

Objective:

Postsecondary educational attainment is the key for successful transition to adulthood, economic self-sufficiency, and good mental and physical health.

Method:

Secondary analyses of school leavers' data were carried out to establish postsecondary educational trajectories of students on the autism spectrum in the United Kingdom.

Results: 
Findings show that students with autism who had attended mainstream secondary schools enter Further Education (post-16 vocational training) and Higher Education (University) institutions at a similar rate to other students to study the full range of subjects on offer. However, they are more likely to be younger, study at a lower academic level, and remain living at home.

Conclusion:

While course completion data were not yet available, attainment data showed that prospects were improving, although more needs to be done to enable these young adults to a achieving their post secondary educational potential.

KEY WORDS: autism spectrum disorder (ASD); school leavers; postsecondary education; secondary data analysis; adults; Higher Education, Further Education. 
RUNNING HEAD: POSTSECONDARY EDUCATION OF STUDENTS WITH AUTISM

Introduction

Postsecondary educational attainment is important for successful transition to adulthood, not only because it is associated with employment prospects and thus economic self-sufficiency, but also because it leads to better mental and physical health outcomes (Milesi, Lansing, Bell, Goerge, \& Stagner, 2010).

For individuals with Autism Spectrum Disorder (ASD), the right to education (Article 24) and the right to work and employment (Article 27) are enshrined in the United Nations Convention of Rights of People with Disabilities (UNCRPD, 2006). While there is some evidence that primary and secondary educational outcomes are improving (Batten, Corbett, Rosenblatt, Withers, \& Yuille, 2006; National Foundation for Educational Research; nfer, 2011a; Treehouse, 2009), 'the gap between "inclusion rhetoric" and "classroom reality" was very wide' (Humphrey \& Lewis, 2008, p.138) and ultimately, little is known about postsecondary educational trajectories of young adults with autism (Chown \& Beavan, 2012; Withers, 2009).

Internationally, prevalence rates for autism spectrum disorder are estimated to be $1 \%$ for adults and $2 \%$ for children (CDC, 2015). In Northern Ireland, ASD prevalence rate in school children is $2.2 \%(n=5,458)$; over 400 of these children are leaving school annually (DHSSPS, 2015). In fact, these figures are likely to be an underestimation. A recent secondary data analysis of the UK-wide Millennium Cohort Study ( $n=18,000+$ ) reported autism prevalence rates of 3.5\% of 11-year old children (Dillenburger, Jordan, \& McKerr, 2014).

In Australia, the charity Autism Asperger Advocacy Australia (A4, 2015) indicated that, based on Carer Allowance data, ASD prevalence rates were approx. 2\% 
RUNNING HEAD: POSTSECONDARY EDUCATION OF STUDENTS WITH AUTISM

for children (5-15 years of age). Yet, the Australian Bureau of Statistics (ABS, 2015) published a more conservative estimate of ASD prevalence rates around $0.5 \%$ overall (based on the Survey of Disability, Ageing and Carers (SDAC), 2012).

While underestimation of prevalence rates of autism in Australia remains a hotly debated issue (Roth, 2013), a focus on the opportunities for young adults with autism is particularly important, given that autism awareness in the general population now seems to be good (e.g., in Northern Ireland, $82 \%$ of adults in the general population are aware of autism; Dillenburger, Jordan, McKerr, Devine, \& Keenan, 2013) and attitudes towards the employment of adults with ASD are improving, e.g., $12 \%$ of the general population would use a business more often, if it had an explicit policy of employing adults on the autism spectrum (Dillenburger, McKerr, Jordan, Devine, \& Keenan, 2014).

Peers are increasingly aware of autism. A recent Northern Irish general population survey of 11 year-olds (total response $n=2319$ ) found that $50 \%$ of these children knew about autism, in fact $2.7 \%$ self-identified as being on the autism spectrum. These figures increased for 16 year-olds (total response $n=1014$ ), $80 \%$ of whom knew about autism and 3.1\% identified themselves as being on the spectrum (Dillenburger, McKerr, \& Jordan, 2015). Of course, these kinds of self-report data cannot be taken as absolute, however the proportion of the children who identified as having autism concurs with findings from the Millennium Cohort Study mentioned earlier (Dillenburger et al., 2014).

Evidence-based interventions are the key to success in the education of children with autism (Dillenburger, 2015; Dillenburger, McKerr, \& Jordan, 2014; Keenan, 2015; National Autism Center (NAC), 2015). Generally, long-term outcomes for those who 
RUNNING HEAD: POSTSECONDARY EDUCATION OF STUDENTS WITH AUTISM

have not received evidence-based early behavioural interventions are very poor (Howlin, Goode, Hutton, \& Rutter, 2004). In fact, Howlin, Savage, Moss, Tempier, and Rutter (2014) found that for $75 \%$ of the adults with autism $(n=60)$ they followed up 40 years after diagnosis, IQ had not improved over time; the remaining $25 \%$ of adults with autism in this group could not be assessed due to lack of language and/or challenging behaviours. The picture is similar in Australia, where the availability of evidence-based behavioural interventions is not consistent despite Government guidelines (Prior \& Roberts, 2012).

In the UK, children with special educational needs (approximately $21,1 \%$ of the overall school population) generally attend mainstream schools, in line with the Salamanca Statement and Framework for Action on Special Needs Education (UNESCO, 1994), the worldwide consensus on future directions for special needs education that proclaims:

We, the delegates of the World Conference on Special Needs Education representing ninety-two governments and twenty-five international organizations, assembled here in Salamanca, Spain, from 7-10 June 1994, hereby reaffirm our commitment to Education for All, recognizing the necessity and urgency of providing education for children, youth and adults with special educational needs within the regular education system, and further hereby endorse the Framework for Action on Special Needs Education, that governments and organizations may be guided by the spirit of its provisions and recommendations. (UNESCO, 1994, p.viii)

Children with specifically high levels of special needs (approx. 2.8\% of the school population) receive a full Statement of Special Educational Needs. Even of the children who have a Statement of Special Educational Needs only $44.4 \%$ attend special schools, while $46.3 \%$ are in mainstream schools, and $9.3 \%$ in other kinds of school provision (DfE, 2014; Perry, 2015). 
RUNNING HEAD: POSTSECONDARY EDUCATION OF STUDENTS WITH AUTISM

Higher levels of participation in postsecondary education is associated with secondary education experiences, i.e., those who attended mainstream secondary education are more likely to achieve better outcomes than those who attended special education. In addition, parental expectations are influential, as are household income and academic ability (Chiang, Cheung, Hickson, Xiang, \& Tsai, 2012).

Postsecondary education aims to foster independence, equality, inclusion, as well as vocational and social skills. However, despite aspirations of adults with ASD to engage in postsecondary education, participation is limited by concerns about not being accepted socially within the adult education institutions (Camarena \& Sarigiani, 2009).

To date, most of what is known about postsecondary education outcomes for adults with ASD comes from the USA. For example, a secondary data analysis of the National Longitudinal Transition Study 2 (NLTS2) shows that, compared to individuals with other disabilities, young people with autism are much less likely to have any form of engagement in employment, education, or training, i.e., as many as $43 \%$ do not transition to postsecondary education or training (Newman et al., 2011; Shattuck et al., 2012). In Australia, the great majority (81\%) of the young people with autism who leave school do not complete a post-school qualification (A4, 2015).

The situation is similar in the UK, where one third of young people with autism aged 16 to 24 years-of-age end up Not-in-Education-Employment-or-Training (NEET) (Bancroft, Batten, Lambert, \& Madders, 2012); that is more than twice the rate in the general population (Department for Education, 2012b). 
RUNNING HEAD: POSTSECONDARY EDUCATION OF STUDENTS WITH AUTISM

The present investigation presents a comprehensive analysis of post-secondary educational trajectories of students with autism who attended mainstream schools, in the UK, specifically in Northern Ireland (NI).

For diagnostic purposes, the International Classification of Disease (ICD)-10 (World Health Organisation, 2014) is used more widely in the UK relative to the Diagnostic and Statistical Manual (DSM; APA, 2013). The ICD-10 retains the distinction between autism and 'Asperger's Syndrome' (F84.5). Although quite recently, the DSM-5 removed this differentiation (APA, 2013), the term Asperger's Syndrome is used in ICD10 as well as in 'historic' data and many individuals diagnosed with Asperger's Syndrome continue to associate with this label, as it 'is considered part of their identity or may reflect a peer group with whom they identify' (Autism Speaks, 2016). Given that the secondary data analyses reported here relate to adults who were diagnosed either with IDC-10 or pre-DSM-5 results reported here include the differential diagnosis.

Basic school leavers' qualifications in the UK, i.e., General Certificate of Secondary Education (GCSE) are assessed in a number of core and optional subject areas. The benchmark for good school outcome is set for 16 year-old school leavers at achieving 5 GCSEs with grades $A^{*}$-C (or equivalent), $A^{*}$ being the top mark; E and D given for low attainment, and F given for 'fail'.

With regards to post-secondary education, Further Education colleges offer courses at Entry level (below GCSE level); Level 1 (GCSE grades D-G); Level 2 (GCSE grades $\mathrm{A}^{*}$-C); Level 3 (Advanced (A) level); and Higher Education Level (Undergraduate degree). Higher Education institutions offer courses in a range of academic and professional subject areas leading to Foundation Degrees, Bachelor Degrees, Masters Degrees, and Doctoral Degrees. 
RUNNING HEAD: POSTSECONDARY EDUCATION OF STUDENTS WITH AUTISM

\section{Method}

Ethical approval for the study was obtained from the Research Ethics Committee of the School of Education, Queens University Belfast (QUB). The study was conducted according to QUB Research Governance and Data Storage guidelines. The study was part of a large scale, 3-year research project funded by the Office of the First and Deputy First Minister, Northern Ireland. Further information and full reports can be downloaded from http://tinyurl.com/p77belh.

Datasets

The following datasets were included in this secondary data analysis:

School Leavers Survey (SLS): The School Leavers Survey is an email-based survey that is carried out annually by the Department of Education Northern Ireland (DENI) to identify qualifications and destinations of school leavers. The School Leavers Survey is conducted in mainstream post-primary schools in Northern Ireland; special schools and independent schools are not included. While the majority of pupils with autism attend publicly funded mainstream schools, the omission of special school ${ }^{1}$ data obviously is a limitation in respect of gaining a full picture of attainment for these school leavers.

In contrast, in Australia some $11.5 \%$ of the schools are in the independent sector, serving $16 \%$ of the school population (Independent Schools Council of Australia, 2015).

1 Only $1.4 \%$ of the total school population attend the 40 special schools in Northern Ireland (DENI 2015; nfer $2011 \mathrm{~b}$ ), while $0.2 \%$ attend non-funded independent schools (nfer $2011 \mathrm{~b}$ ); there were 15 registered independent schools in 2013/2014 (DENI 2016), The Census of independent UK schools indicated that 5.4\% of their pupils with Special Needs have been diagnosed with 'ASD or Asperger's Syndrome' (Independent Schools Council 2015, p.16). 
RUNNING HEAD: POSTSECONDARY EDUCATION OF STUDENTS WITH AUTISM

Detailed procedural guidance regarding the School Leavers Survey is available (DENI, 2014). Subject to disclosure control, figures for students with autism were aggregated between 2008-2012.

Further Education Statistical Record (FESR): The Further Education Statistical Record was compiled by the Northern Irish Department for Employment and Learning (DEL) to monitor the Further Education sector on a range of different measures. For the secondary data analysis, figures were broken down along some key variables, including ASD designation, i.e., students with autism and students without ASD, academic year, age band, mode of attendance (full-time vs part-time), qualification rate, and attendance rate. Department for Employment and Learning (DEL) figures were based on full-year student enrolments analysed in accordance with the Governmental statistics guidelines (UK Statistics Authority, January 2009). However, given that Further Education students can be enrolled on more than one course, the actual student numbers may differ from enrolment figures. Furthermore, some students were enrolled for part of the year, i.e., they may have changed or dropped out of a course. Students were not required to declare their disability, and therefore the figures may underestimate the prevalence of ASD. At the same time, students with autism could be registered under 'learning disability' or under 'more than one disability' and therefore not included in a data search for ASD, which could further underestimate the prevalence, and these limitations, which are beyond the control of the authors, will be discussed later. Finally, in accordance with Further Education Statistical Record (DEL, December 2012a), all figures were rounded up or down to the nearest 5 , with numbers 0,1 , and 2 rounded to 0. 
RUNNING HEAD: POSTSECONDARY EDUCATION OF STUDENTS WITH AUTISM

Further Education in other devolved regions: In England, the Further Education and Skills Analysis Department produced and published prevalence data about students with autism and these were used for comparative purposes. However, due to data quality and disclosure concerns (e.g., small frequencies), data by course subjects were not available. The Welsh Government published ASD prevalence data for Further Education in their statistical analysis in 2012 and 2013. However, students in Wales were only asked to declare their disability if it impacted on their ability to learn and/or use general facilities and thus it was likely that the reported numbers exclude some students with autism. The Scottish Funding Council (SFC) data on Further Education enrolments did not include categories for social/communication impairments and Asperger's Syndrome/ASD until academic year 2013/14.

Higher Education Statistics Agency (HESA): The Higher Education Statistics Agency records included a general code for 'disability' since 1994/95. In 2004/05, the separate category of ASD was added. In 2010/11, the code 'ASD' was replaced with 'social/communicative impairment such as Asperger's Syndrome/other autistic spectrum disorder' (cf., HESA, 2012/13; Equality Challenge Unit (ECU), 2013). The code, 'Autistic Spectrum Disorder', remained in use for students who were already recorded on the system under ASD, although this only applied to very few students. For the present analysis, the Department of Employment and Learning (DEL) provided information on the number of students enrolled at Higher Education Institutions (HEI). The Higher Education Statistics Agency (HESA) quality assured data are reported here.

\section{Results}


RUNNING HEAD: POSTSECONDARY EDUCATION OF STUDENTS WITH AUTISM

Qualifications of school leavers

Nearly three quarters (72\%) of pupils without autism achieved good school leaver outcomes (i.e., 5 GCSEs with grades $A^{*}-$ C); only $28 \%$ of children without ASD left school without these qualifications. In contrast, only 33\%-51\% of of school leavers with ASD achieved 5 GCSEs with grades A*-C, while 49\%-67\% of students with ASD achieved fewer than 5 GCSEs with these grades (Figure 1).

\section{Post-secondary education destinations}

Most (94\%) school leavers (irrespective of ASD diagnosis) transitioned onto other educational or training settings; only 3\%-4\% faced unemployment upon leaving school (Figure 2). However, only $9 \%-22 \%$ of students with autism transitioned into Higher Education (compared to $42 \%$ of students without autism). The vast majority of school leavers with autism (69\%-81\%) transitioned to Further Education (FE) or training (compared to $45 \%$ students without autism).

Postsecondary education data for Further Education and Higher Education of students with ASD have been recorded only recently across the UK (Figure 3). In NI, the total ratio of students with ASD in Further Education (FE) rose from $0.01 \%-0.7 \%$, while in England, where records began as recently as 2008 (Data Service, 2014), enrolments rose from 0.12\%-0.46\%; in Wales records began in 2010 and the rate of students with ASD in Further Education rose from 0.22\%-0.26\% (Figure 4).

In Higher Education (HE), the inclusion rate for first year undergraduate students increased from $0.04 \%$ to $0.14 \%$ between 2004 and 2010 (HESA, 2006; 2011). English enrolment figures were consistently lower than Northern Irish enrolment figures (difference of 0.16 to 0.27 percentage points). 
RUNNING HEAD: POSTSECONDARY EDUCATION OF STUDENTS WITH AUTISM

Most of the students with autism were very young, i.e., $80 \%$ were $<19$ years old and only $8 \%$ were $>25$ years-of-age, while students without autism were generally older, i.e., $54 \%$ were $<19$ years old and $33 \%$ were $>25$ years of age. With regards to gender, enrolment figures were in line with the well-established 4:1 male: female ratio of ASD (Elsabbagh et al., 2012), i.e., 76\% of students with autism were male and 24\% were female (compared to a 50\%:50\% male: female ratio for students without autism).

\section{Mode and area of study in Further Education}

Students with autism were enrolled at all study levels, although more students with autism were enrolled in Entry Level or Level 1 compared to students without autism, (37\% vs 23\%), while fewer students with autism studied at Level 3 or above compared to students without autism (16\% vs $23 \%$ ). These figures were relatively stable across time.

In Further Education colleges the vast majority of enrolments for all students were part-time. The attendance mode was similarly distributed for students with and students without autism, with a relatively small preference for full-time courses for students with autism (Figure 5); enrolment rates were relatively stable across time.

Subject categories used in the present analysis were based on the Qualifications and Curriculum Authority (QCA, 2004), the Council for the Curriculum, Examinations and Assessment (CCEA), and the ACCAC (Welsh authority), and while gender related subject preferences cannot be completely discounted, a differential analysis for gender was not possible, due to small cell counts. To avoid small numbers, data from 2009/10 2011/12 were combined (Figure 6). 
RUNNING HEAD: POSTSECONDARY EDUCATION OF STUDENTS WITH AUTISM

The most popular courses focussed on Education and Training with high enrolment figures both for students with autism (32\%) and students without autism (22\%). Courses focussing on Preparation for Life and Work were taken more than twice as often by students with autism (17\%) than by students without autism (8\%).

\section{Retention and achievement at Further Education colleges}

Figure 7 shows final year retention rates provided by Department of Employment and Learning (DEL). In both 2010/11 and 2011/12, retention rates for students with autism were slightly higher than retention rates for students without autism (1.5-1.9 percentage points).

Achievement rates were calculated as the proportion of students who completed final year and met the course targets, either fully or partially. Achievement rates were very similar for both groups, separated by only one percentage point (Figure 8).

\section{Enrolment at Higher Education Institutions}

Of the nearly 52,000 Higher Education Institutions (HEI) enrolments in 2011-12 in Northern Ireland, $0.45 \%(n=235)$ were students with autism, while in rest of the United Kingdom only $0.17 \%$ of all Higher Education Institution students reported they had autism (Figure 9). This was a rise by 0.17 percentage points in Northern Ireland (Cohen's $d=0.26$ ) and 0.04 percentage points Great Britain (Cohen's $d=0.15$ ) from the previous year, where $0.28 \%(n=145)$ of Higher Education Institution students had ASD 
RUNNING HEAD: POSTSECONDARY EDUCATION OF STUDENTS WITH AUTISM

in Northern Ireland, while in the rest of the UK only $0.13 \%$ of Higher Education Institution students reported having ASD.

Approximately nine out of ten students with autism (89-90\%) studying at Higher Education Institution in Northern Ireland were from Northern Ireland. This figure was slightly lower for students without autism (83-85\%) (Figure 10). The remaining 10$11 \%$ students with autism at Northern Irish Universities were from other parts of the United Kingdom (i.e., England, Scotland, or Wales), Republic of Ireland (ROI), other parts of the European Union (EU), and overseas.

Figure 11 shows that students with autism from Northern Ireland (16-13\%; 2010/11 and 2011/12 respectively) were less likely to study at Higher Education Institutions outside of Northern Ireland, than students without autism (33-34\%; 2010/11 and 2011/12 respectively).

With regard to gender distribution, just over half of students with autism in Higher Education Institutions were male (53\%), while 47\% were female. This figure indicates a overrepresentation of females in the cohort, compared to childhood autism diagnosis ratios for male: female of 4:1 (Elsabbagh et al., 2012). However, it is similar to general enrolment figures for students without autism, where the male: female ratio was $42 \%$ and $58 \%$ (cf., DEL, 2013).

\section{Mode and area of study in Higher Education}

Students with autism studied the full range of subjects offered at Higher Education Institutions in Northern Ireland. Subjects with $<1 \%$ enrolments were excluded from the analysis, as sensitivity analysis showed that using small numbers 
RUNNING HEAD: POSTSECONDARY EDUCATION OF STUDENTS WITH AUTISM

would result in an unacceptable margin of error. In addition, to mitigate the effects of rounding small numbers, very small differences were not included. Consequently, Agriculture, Building and Planning; Mathematical Sciences; Combined; and Veterinary science were not included in the analysis.

Figure 12 shows that Business and Administrative Studies was a popular subject choice for students with autism (4\%) although this rate was more than four times greater for students without autism (17\%). Education also tended to be less popular amongst students with autism (7\%) than with students without autism (12\%), as was languages (1\% vs 4\%, respectively) (Figure 13). Students with autism were more likely to study Subjects Allied to Medicines than were students without autism (28\% vs 15\%). The enrolment rate in Mass Communications and Documentation for students with autism was nearly double that of students without autism.

In Great Britain, students with autism preferred a number of subjects compared to students without autism, including Computer Science (15\% vs 4\%), Creative Arts and Design (16\% vs 7\%), Historical and Philosophical Studies (8\% vs 4\%), Mathematics (5\% vs $2 \%$ ), and Mass Communications and Documentation (4\% vs 2\%). In contrast, students with autism were less likely to select other areas of study, when compared with student without ASD, including Medicine and Dentistry (0.3\% vs 3\%), and Subjects Allied to Medicine (3\% vs 12\%).

\section{Retention and achievement at Higher Education Institutions}

Retention and achievement rates for Higher Education students with ASD are only just emerging. Over the two years that data were available (2010/11 and 
RUNNING HEAD: POSTSECONDARY EDUCATION OF STUDENTS WITH AUTISM

$2011 / 12$ ), there was an increase in the relative proportion of students with autism who completed university successfully ( 0.23 vs $0.31 \%$, respectively). This increase mirrored the increase in new enrolments over these two years $(0.28 \%$ vs $0.45 \%)$ and therefore potentially indicates good completion rates.

\section{Discussion}

In light of rising prevalence rates of ASD in the school population (Dillenburger, Jordan, \& McKerr, 2014), the lack of research on postsecondary educational trajectories is worrying (Chown \& Beavan 2012). Most research to date has been based on findings from the USA, often using the NLTS2 survey data (e.g. Newman et al., 2011), and little is known about how well students with autism are faring in postsecondary education in other countries. The findings presented here are based on data from the United Kingdom (UK) (i.e., NI and Great Britain (GB), which included England, Scotland and Wales) and therefore make a valuable contribution to the understanding internationally, of what happens to students with autism after they leave compulsory education.

Qualifications and destinations of school leavers

The secondary data analysis of the Northern Irish School Leavers Survey (SLS) identified differences and similarities of qualifications and destinations of students with ASD and students without autism, when they leave mainstream education. On a positive note, students with autism were not at greater risk of leaving school to unemployment than other students. However, there were some notable differences. Students with 
RUNNING HEAD: POSTSECONDARY EDUCATION OF STUDENTS WITH AUTISM

autism were more likely to leave mainstream education with lower educational achievements, i.e., with fewer than 5 GCSE grade $A^{*}$-C or equivalent. In addition, students with autism were more likely than their peers without autism to enrol in Further Education Colleges rather than in Higher Education Institutions.

The School Leavers Survey did not include special schools (i.e., data were not available), so unfortunately the findings reported here cannot be generalised to students with autism who leave special schools. Although the majority of pupils with autism in the UK attend mainstream secondary schools, future School Leavers Surveys should collect data on destinations of special school leavers in order to gain a better indication of the proportion who enter into further and higher education. Alternatively, future research could use data linking between the secondary and postsecondary datasets to provide this information (using unique pupil numbers).

Prevalence rates of students with autism in Further Education colleges and Higher Education Institutions

Using data sets provided by the Department of Employment and Learning (DEL), the secondary data analysis reported here showed a clear upward trend in proportions of Further Education and Higher Education enrolments of students with autism in recent years. This may be due to overall increased prevalence of ASD and subsequently, improved public autism awareness (Dillenburger et al., 2013) and positive attitudes towards the inclusion of students with autism (Dillenburger et al., 2014; Mavropoulou \& Sideridis, 2014), and/or the Widening Participation initiative (DEL, 2010) aimed at improving student disability services. 
RUNNING HEAD: POSTSECONDARY EDUCATION OF STUDENTS WITH AUTISM

Enrolments data in England (Data Service, 2014) showed that the prevalence rate for Further Education enrolments of students with autism had tripled since it was first recorded in 2008/09, to 0.46\% (2011/12), however English enrolment figures were consistently lower than Northern Irish enrolment figures (a difference of 0.16 to 0.27 percentage points). The reasons underlying this discrepancy could be multiple, e.g. different disclosure rates, differences in coding or lower proportion of students with autism attending Further Education.

Higher Education data revealed a substantial increase in the number of enrolments of students with autism at Northern Irish Universities from $0.28 \%$ to $0.45 \%$, much higher than the respective figures for Universities in Great Britain (from $0.13 \%$ to $0.17 \%)$. It is important to bear in mind that the actual enrolment figures could be higher as many students at University have undiagnosed ASD. In fact, it has been estimated that $0.7 \%-1.9 \%$ of University students could have ASD, often undiagnosed (White, Ollendick, \& Bray, 2011). Unfortunately, students with undiagnosed ASD are missing out on available support.

Given present prevalence estimates in the adult population of approx. 1\% (Elsabbagh et al., 2012; Kim et al., 2011) and an established 50-70\% prevalence of cooccurring intellectual disabilities (Buescher, Cidav, Knapp, \& Mandell, 2014; Matson \& Shoemaker, 2009), the fact that nearly $0.5 \%$ of Higher Education students have ASD means that students with autism are well represented at Northern Ireland Higher Education Institutions. It would be interesting to see how well students with autism are represented at Universities in other countries. 
RUNNING HEAD: POSTSECONDARY EDUCATION OF STUDENTS WITH AUTISM

Students with autism in Further Education

Students with autism in Further Education colleges were more likely to be $<19$ years-of-age than students without autism. This is unsurprising given that ASD prevalence rates tend to be higher in younger people (Centers for Disease Control; CDC, $2012,2013)$. This could be due to multiple factors, including broadening of the diagnostic criteria, accuracy of case identification, under diagnosis in older adults, and awareness amongst professionals.

Overall achievement and completion rates for these Further Education courses were very positive; there was evidence that students with autism were just as likely as their peers to complete their course and gain a qualification. However, the Northern Irish data show that students with autism were more likely to study at lower levels, e.g., Level 1 and entry level courses, than students without autism. Compared to students without autism, they were more likely to enrol onto Education and Training; Arts, Media and Publishing, and History, Philosophy and Theology courses. Enrolments onto courses covering Preparation for life and work were twice as common for students with autism compared to their peers.

Course choice may be explained to some extent, by gender, as ASD is more frequent in males (Elsabbagh et al., 2012) and males tend to study certain subjects more than females (cf., DEL, 2012b), e.g., Engineering and Manufacturing Technologies; Leisure, Travel and Tourism; Agriculture, Horticulture and Animal Care. These courserelated data may be particular valuable for employment support services, for example, with regards to establish partnerships with employers in the relevant sectors. 
RUNNING HEAD: POSTSECONDARY EDUCATION OF STUDENTS WITH AUTISM

The Northern Irish data reported here are much more detailed than data available for England (Data Service, 2014) and Wales (Welsh Government, 2012). We contacted United Kingdom statistical teams for data not in the public domain, however, only Northern Irish agencies were in the position to provide comprehensive Further Education data for students with autism. This is unfortunate, as without data such as retention and achievement rates it is difficult to assess how well individuals with ASD are being included in adult education in the rest of the United Kingdom.

Students with autism in Higher Education

Data on students with autism in Higher Education for the whole of the United Kingdom were available across region from the Higher Education Statistics Authority. Most of the students with autism from Northern Ireland stayed in Northern Ireland to study, however some went to University elsewhere. The reasons why so many students with autism were reluctant to relocate to go to University away from home may be related to general mobility difficulties (Jansiewicz, Goldberg, Newschaffer, Denckla, Landa, \& Mostofsky, 2006) and support needs (Stewart, 2008), that were better served by studying from home. However, it remained unclear whether students with autism were happy to go to University in Northern Ireland or if they would have preferred a course elsewhere but felt that there were barriers preventing them from doing so. Further research should explore the personal reasons for college and subject choices.

The issues around gender were also interesting. While the gender distribution in ASD is generally acknowledged to be $4: 1$ in favour of males, this was not reflected in Higher Education enrolments, i.e., at a near 40:60 distribution women were 
RUNNING HEAD: POSTSECONDARY EDUCATION OF STUDENTS WITH AUTISM

overrepresented among students with autism. It was unclear whether this was related to female students with autism feeling better supported, and thus more able to attend Higher Education Institutions or whether they were more willing to seek help and disclose their diagnosis to Higher Education disability services.

Students with autism differed from students without autism in terms of the subjects studied and it may be that some of these differences can be attributed to gender differences. Some Higher Education subjects traditionally are favoured by one gender over the other, e.g., traditionally, female dominated subjects include Subjects Allied to Medicine, Social Studies, Education, and Languages (DEL, 2013) and traditionally male dominated subjects include Engineering and Technology. Ultimately, care must also be taken when interpreting the Higher Education subject data as it was not possible to verify some of the findings, such as the relatively high enrolment figures for students with autism studying Subjects Allied to Medicine, such as Nursing. The numbers of students with ASD who were enrolled in these courses was unexpected, and although we made extensive efforts to verify these figures, they could not be confirmed and it is advisable that caution should be taken when interpreting these data.

Comparative Higher Education achievement data for students with autism were not available yet. This is primarily because the current recording method for ASD had not been in place for long enough to yield outcome data. When these data become available they will be particularly important for future planning and tailoring employment programmes. 
RUNNING HEAD: POSTSECONDARY EDUCATION OF STUDENTS WITH AUTISM

Despite the increasing numbers of students with autism who fulfil their educational potential in Further and Higher Education, many may still leave school without obtaining 5 GCSE passes $\left(A^{*}-\mathrm{C}\right)$ or equivalent, have had extended periods of absences or exclusions from school (Ambitious about Autism 2014a; Dillenburger, Jordan \& McKerr 2014), and are likely to have experienced bullying (Bancroft et al, 2012; Sofronoff, Dark, \& Stone 2011). For these students, Further and Higher Education Institutions are not accessible and specialist colleges have developed elsewhere in Europe and the United States. For example, Rea College Pluryn in the Netherlands has been providing vocational education for students with disabilities for over 30 years (Reichrath, 2013). In the USA, there is specific legal support for Third Level education for students with autism through the Americans with Disabilities Act (ADA) and Section 504 of the Rehabilitation Act (Autism Speaks 2014). Some colleges offer tailored on-line degrees for students with autism (ibid.) while others provide support programmes across a range of courses for students with autism, such as Marshall University, West Virginia, which offers a 'positive behaviour support' system to students to help them achieve success in their chosen field (Marshall University 2014). More than 70 specialist post-16 colleges, including those specifically for students with challenging behaviours, exist in Great Britain (Association of National Specialist Colleges [Natspec] 2014). A very recent development, founded specifically for students with autism, is Ambitious College in London, which opened in September 2014 on the campus of Barnet and Southgate College, London (Ambitious about Autism 2014b; Ambitious College 2015). In Ireland, Dublin City University is aiming to become the first European autism friendly University campus (Harris, 2016). 
RUNNING HEAD: POSTSECONDARY EDUCATION OF STUDENTS WITH AUTISM

The educational options for lower achieving students are relatively limited in Northern Ireland; no specialist colleges exist. Although a number of non-statutory providers are experimenting with alternative forms of postsecondary education, it is difficult to identify them as, unlike the Combating Autism Act of 2006 (renewed in 2011) in the US, there is no obligation under the Autism Act NI (2011) to provide a continuing education curriculum or to make available information on evidence-based interventions and resources (Dillenburger, McKerr, \& Jordan 2014).

Alternative postsecondary training programmes tend to evolve at a local level, with often joint statutory/consortium funding, such as the transition schemes developed by the Liberty Consortium in Derry for students with learning disabilities and/or autism (Dobbin 2014), and the Print Room in Armagh which provides vocational training and the opportunity to acquire qualifications with an accredited provider on site for young people who have disengaged with education (Appleby Trust 2013).

Data gaps, limitations, and recommendations

Self-declaration remained one of the key limitations of the available data sets. In order to access support through Further Education or Higher Education Institution disability services a student has to self-declare that they have a disability. For many reasons, including equality and confidentiality, it is not mandatory for a student to selfdeclare disabilities and evidence of an actual ASD diagnosis generally is not necessary. Therefore, the figures presented here may underestimate the actual number of students with autism attending Further and Higher Education Institutions. 
RUNNING HEAD: POSTSECONDARY EDUCATION OF STUDENTS WITH AUTISM

While currently Northern Ireland records a relative wealth of data on ASD in postsecondary education, there is room for improvement, especially across the rest of the United Kingdom. The Further and Higher Education datasets recorded individuals with more than one disability under 'multiple disability' meaning that it was not possible to identify students who declared having ASD alongside co-occurring diagnoses. In order to provide more accurate measures, all disabilities (including Autism Spectrum Disorder) should be recorded separately.

Additionally, it would be desirable to see the School Leavers Survey extended, especially as many of the students attending special schools are likely to have more profound disabilities and the information regarding their outcomes is just as critical for assessment, improvements, and futures planning as are the data for students with ASD who are able to attend mainstream schools. Data on destinations of Special School leavers would allow for a better indication of their postsecondary educational trajectories. Alternatively, data linking between the secondary and postsecondary datasets could provide this information (using unique pupil numbers).

The present secondary data analysis has revealed what postsecondary education data are available in Northern Ireland and other regions of the United Kingdom. It would be useful for other countries to conduct similar reviews of existing data sources, so that international comparisons can be made and best practice can be identified.

\section{References}

Ambitious about Autism (2014a). Ruled out. Why are children with autism missing out on education? Retrieved from the Web 17/02/2014 
RUNNING HEAD: POSTSECONDARY EDUCATION OF STUDENTS WITH AUTISM

www.ambitiousaboutautism.org.uk/page/who_we_are/news/article/index.cfm? articleId $=335$

Ambitious about Autism (2014b). Ambitious College. Retrieved from the Web $17 / 07 / 2014$ http://www.ambitiousaboutautism.org.uk/page/what_we_do/ambitious_college .$c f m$

Ambitious College (2015). About Us. Retrieved from the Web 24/01/2016 http://www.ambitiouscollege.org.uk/about-us

American Psychiatric Association (2013). Diagnostic and Statistical Manual of Mental Disorders, fifth edition. Retrieved from http://www.psychiatry.org/psychiatrists/practice/dsm/dsm-5Appleby Trust (2013). The Print Room: Specifically ASD. Retrieved from the Web 17/02/2014 http://applebyprintroom.com/

Association of National Specialist Colleges [Natspec] 2014). Natspec College Directory. Retrieved from the Web 17/07/2014 www.natspec.org.uk/directory/

Australian Bureau of Statistics [ABS] (2015). Australian Demographic Statistics. Australian Bureau of Statistics. Retrieved from the Web 29/02/2016, from http://www.ausstats.abs.gov.au/Ausstats/subscriber.nsf/0/801757AC98D5DE8 FCA257F1D00142620/\$File/31010_jun 2015.pdf

Autism Act (Northern Ireland) 2011. (2011). Chapter 27. Retrieved from the Web 17/07/2014 www.legislation.gov.uk/nia/2011/27/2011-05-09 
RUNNING HEAD: POSTSECONDARY EDUCATION OF STUDENTS WITH AUTISM

Autism Asperger Advocacy Australia [A4] (2015). Autism prevalence in Australia 2015.

Retrieved from the Web 25/01/2016 http://a4.org.au/prevalence2015

Autism Speaks (2014). Postsecondary Education Resources. Retrieved from the Web 17/07/2014 www.autismspeaks.org/family-services/resourcelibrary/postsecondary-education-resources

Autism Speaks (2016). Answers to Frequently Asked Questions about DSM-5. Retrieved from the Web 27/01/2016 https://www.autismspeaks.org/dsm-5/faq

Australian Bureau of Statistics. (2012). Prevalence of autism. Australian Bureau of Statistics. Retrieved from the Web 28/1/ 2016 http://www.abs.gov.au/ausstats/abs@.nsf/Latestproducts/4428.0Main Features32012?opendocument\&tabname=Summary\&prodno $=4428.0 \&$ issue $=2012$ \&num $=\&$ view $=$

Baird, G. (2014). Commentary: Diverging trajectories from a similar starting point: the outcome in adults whose autism was diagnosed in childhood--reflections on Howlin et al. (2013). Journal of Child Psychology and Psychiatry, and Allied Disciplines, 55(1), 59-60. doi:10.1111/jcpp.12182

Bancroft, K., Batten, A., Lambert, S., \& Madders, T. (2012). The way we are: autism in 2012. London: National Autistic Society. Retrieved from the Web 17/07/2014 www.autism.org.uk/get-involved/50th-birthday/survey-report.aspx

Batten, A., Corbett, C., Rosenblatt, M., Withers, L., \& Yuille, R. (2006). Make school make sense. Autism and education: the reality for families today. London: National Autistic Society. Retrieved from the Web 17/07/2014 
RUNNING HEAD: POSTSECONDARY EDUCATION OF STUDENTS WITH AUTISM

www.autism.org.uk/ /media/NAS/Documents/Extranet/Autism-

library/Magazines-articles-and-reports/Reports/Our-

reports/make\%20school\%20make\%20sense\%20full\%20report.ashx.

Buescher, A. V. S., Cidav, Z., Knapp, M., \& Mandell, D. S. (2014). Costs of Autism Spectrum Disorders in the United Kingdom and the United States. JAMA Pediatrics, 168, 721728. doi:10.1001/jamapediatrics.2014.210

Camarena, P.M., \& Sarigiani, P.A. (2009). Postsecondary educational aspirations of highfunctioning adolescents with autism spectrum disorders and their parents. Focus on Autism and other Developmental Disabilities, 24, 115-128.

Centers for Disease Control (CDC). (2015). Autism Spectrum Disorder (ASD): Data and statistics. Centers for Disease Control and Prevention. Retrieved January 28, 2015, from http://www.cdc.gov/ncbddd/autism/data.html

Centers for Disease Control (CDC). (2013). Changes in prevalence of parent-reported Autism Spectrum Disorder in school aged U.S. children. 2007 to 2011-12. National Statistics Reports.

Centers for Disease Control (CDC). (2012). Prevalence of Autism Spectrum Disorders. Autism and Developmental Disabilities Monitoring Network, United States, 2006. Surveillance Summaries. Morbidity and Mortality Weekly Report. December 18, 58 (SS10), 1-19. 
RUNNING HEAD: POSTSECONDARY EDUCATION OF STUDENTS WITH AUTISM

Chiang, H-M., Cheung, Y.K., Hickson, L. Xiang, R., \& Tsai, L.Y., (2012). Predictive factors of participation in postsecondary education for high school leavers with autism. Journal of Autism and Developmental Disorders, 42, 685-696.

Chown, N. \& Beavan, N. (2012). Intellectually capable but socially excluded? A review of the literature and research on students with autism in further education. Journal of Further and Higher Education, 36, 477-493.

Combating Autism Act (2006). Bill summary \& status 109th congress (2005-2006) S.843 CRS summary. Retrieved from the Web 17/07/2014 http://thomas.loc.gov/cgibin/bdquery/ z?d109:SN00843:@@@D\&summ2=m\&

Data Service (2014). Equality and Diversity Statistics. Retrieved from the Web $17 / 07 / 2014$ www.thedataservice.org.uk/Statistics/fe_data_library/further_education_skills/eq uality_and_diversity/

Department of Education Northern Ireland (DENI) (2016). Independent Schools: A list of Independent Schools currently registered in Northern Ireland. Retrieved from https://www.deni.gov.uk/articles/independent-schools

Department of Education Northern Ireland (DENI) (2015). Review of Special School Provision in Northern Ireland: A Ministerial Working Group Report. Retrieved from https://www.deni.gov.uk/sites/default/files/publications/de/Review\%20of\%20S pecial\%20School\%20Provision\%20in\%20Northern\%20Ireland\%282\%29.pdf 
RUNNING HEAD: POSTSECONDARY EDUCATION OF STUDENTS WITH AUTISM

Department of Education Northern Ireland (DENI) (2014). School leavers: Survey procedural guidance. DENI: Bangor. Retrieved from the Web 17/07/2014 http://www.deni.gov.uk/school_leavers2013.pdf

Department for Employment and Learning Northern Ireland (DEL) (February 2013). Statistical Bulletin: Enrolments at UK Higher Education Institutions: Northern Ireland analysis 2011/12. Belfast: DEL. Retrieved from the Web 17/07/2014 www.DEL.gov.uk/he-enrolments-2011-12.pdf

Department for Employment and Learning Northern Ireland (DEL) (December 2012a). DEL confidentiality statement. Belfast: DEL. Retrieved from the Web 17/07/2014 www.DEL.gov.uk/del-confidentiality-statement.pdf

Department for Employment and Learning Northern Ireland (DEL) (December 2012b). Statistical Bulletin: Professional and Technical Enrolments in the Northern Ireland Further Education Sector for 2011/12. Belfast: DEL. Retrieved from the Web 17/07/2014 www.DEL.gov.uk/index/statsandresearch/further-educationstats/fe-enrolments/all-further-education-provision-enrolments/prof-and-techenrolments-in-ni-fe-sector-2011-12.htm

Department for Employment and Learning Northern Ireland (DEL) (October, 2010). Project review of widening participation funded initiatives: report FINAL. Belfast: DEL. Retrieved from the Web 17/07/2014 www.DEL.gov.uk/review-of-wideningparticipation-funded-initiatives-final.pdf

Department of Health, Social Services and Public Safety (2015). The estimated prevalence of autism in school age children in Northern Ireland. Belfast, NI. 
RUNNING HEAD: POSTSECONDARY EDUCATION OF STUDENTS WITH AUTISM

Dillenburger, K. (2014). Evidence-based management and intervention for autism spectrum disorders. In M. Fitzgerald (Ed.), Autism (1st ed.). Intech.

Dillenburger, K., Jordan, J.-A., McKerr, L., \& Keenan, M. (2015). The Millennium child with autism: Early childhood trajectories for health, education and economic wellbeing. Developmental Neurorehabilitation, 18, 37-46. doi:10.3109/17518423.2014.964378

Dillenburger, K., Jordan, J. A., McKerr, L., Devine, P., \& Keenan, M. (2013). Awareness and knowledge of autism and autism interventions: A general population survey. Research in Autism Spectrum Disorders, 7(12), 1558-1567. doi:10.1016/j.rasd.2013.09.004

Dillenburger, K., McKerr, L., \& Jordan, J.-A. (2015). Children and young people's awareness, knowledge, and attitudes towards autism in Northern Ireland. ARK Research Update. Retrieved May 13, 2015, from www.ark.ac.uk

Dillenburger, K., McKerr, L. \& Jordan, J-A. (2014). Project ABLE: Evaluation report. Belfast: The Orchardville Society.

Dillenburger, K., McKerr, L., Jordan, J. A., Devine, P., \& Keenan, M. (2015). Creating an inclusive society... How close are we in relation to Autism Spectrum Disorder? A general population survey. Journal of Applied Research in Intellectual Disabilities, 28(4), 330-340. doi:10.1111/jar.12144

Dobbin, M. (2014). Developing a community/education response to transition-from opportunities to provision. Workshop delivered at Post-19 Conference: "Investigating the Alternatives", Lisburn, Co. Antrim 14.05.14. 
RUNNING HEAD: POSTSECONDARY EDUCATION OF STUDENTS WITH AUTISM

Elsabbagh, M., Divan, G., Koh, Y.-J., Kim, Y. S., Kauchali, S., Marcín, C., ... Fombonne, E. (2012). Global prevalence of autism and other pervasive developmental disorders. Autism Research : Official Journal of the International Society for Autism Research, 5(3), 160-79. doi:10.1002/aur.239

Equality Challenge Unit (ECU; 2013). Personal communication.

Harris, A. (2016). Ireland's first Autism-friendly university might be on the way.... AsIAm. Retrieved January 29, 2016, from https://www.asiam.ie/dcu-announcement Higher Education Statistics Authority (2006). First year UK domiciled HE students by qualification aim, mode of study, gender and disability 2004/05. Cheltenham: HESA. Retrieved from the Web 17/07/2014 www.hesa.ac.uk/index.php/content/view/1973/239/.

Higher Education Statistics Authority (2011). UK domiciled HE students by level of study, gender, mode of study, year of study and disability status 2009/10. Cheltenham: HESA. Retrieved from the Web 17/07/2014 www.hesa.ac.uk/index.php/content/view/1973/239/.

Higher Education Statistics Authority (HESA) (2012/13). Student record 2012/13: All fields disability. Retrieved from the Web 17/07/2014 www.hesa.ac.uk/component/option,com_studrec/task,show_file/Itemid,233/mnl, 12051/href,a\%5E_\%5EDISABLE.html/

Higher Education Funding Council England (HEFCE) (2013). Equality Challenge Unit 2013 progress review. Retrieved from the Web 09/02/2014 www.hefce.ac.uk/pubs/rereports/year/2013/ecuprogress/ 
RUNNING HEAD: POSTSECONDARY EDUCATION OF STUDENTS WITH AUTISM

Howlin, P., Goode, S., Hutton, J., \& Rutter, M. (2004). Adult outcome for children with autism. Journal of Child Psychology and Psychiatry, 45(2), 212-229. doi:10.1111/j.1469-7610.2004.00215.x

Howlin, P., Savage, S., Moss, P., Tempier, A., \& Rutter, M. (2014). Cognitive and language skills in adults with autism: a 40-year follow-up. Journal of Child Psychology and Psychiatry, and Allied Disciplines, 55, 49-58. 10.1111/jcpp.12115

Independent Schools Council of Australia (2016). About Independent Schools. Retrieved 256/01/2016 from http://isca.edu.au/about-independent-schools/

Jansiewicz, E.M., Goldberg, M.C., Newschaffer, C.J., Denckla, M.B., Landa, R., \& Mostofsky, S.H. (2006). Motor signs distinguish children with high functioning autism and Asperger's syndrome from controls. Journal of Autism and Developmental Disorders, 36, 613-621. 10.1007/s10803-006-0109-

Kim, Y. S., Leventhal, B. L., Koh, Y.-J., Fombonne, E., Laska, E., Lim, E.-C., ... Grinker, R. R. (2011). Prevalence of autism spectrum disorders in a total population sample. The American Journal of Psychiatry, 168(9), 904-1

doi:10.1176/appi.ajp.2011.10101532

Marshall University (2014). The College Program for Students with autism spectrum Disorder. Retrieved from the Web 17/07/2014 www.marshall.edu/collegeprogram/

Matson, J. L., \& Shoemaker, M. (2009). Intellectual disability and its relationship to autism spectrum disorders. Research in Developmental Disabilities, 30(6), 1107-14. 14. doi:10.1016/j.ridd.2009.06.003 
RUNNING HEAD: POSTSECONDARY EDUCATION OF STUDENTS WITH AUTISM

Mavropoulou, S., \& Sideridis, G. D. (2014). Knowledge of autism and attitudes of children towards their partially integrated peers with autism spectrum disorders. Journal of Autism and Developmental Disorders, 44(8), 1867-85. doi:10.1007/s10803-0142059-0

Milesi, C., Lansing, J., Bell, K. C., Goerge, R., \& Stagner, M. (2010). Postsecondary Educational Trajectories of Urban Youth: Addressing Vulnerabilities and Barriers to Enrollment and Persistence. Chapin Hall at the University of Chicago: Issue Brief. Retrieved from the Web 26/07/2014 http://www.chapinhall.org/research/brief/postsecondary-educationaltrajectories-urban-youth-addressing-vulnerabilities-and-bar

National Audit Office (NAO) (2009). Supporting people with autism through adulthood. London: The Stationery Office.

National Foundation for Educational Research (NFER) (2011a). NFER Teacher Voice Omnibus February 2011 Survey. Teacher training on autistic spectrum disorders: Ambitious about Autism. Slough: NFER. Retrieved from the Web 17/07/2014 www.nfer.ac.uk/what-we-offer/teacher-voice/AmbitiousaboutAutism.pdf

National Foundation for Educational Research (NFER)(2011b). Overview of education system in Northern Ireland. Retrieved from the Web 26/01/2016 https://www.nfer.ac.uk/shadomx/apps/fms/fmsdownload.cfm?file_uuid=F0931 8EC-C29E-AD4D-0AC2-8B6734A0D694\&siteName=nfer

Newman, L., Wagner, M., Knokey, A-M., Marder, C. Nagle, K. Shaver, D., ... Schwarting, M. (2011). The post-high school outcomes of young adults with disabilities up to 8 years 
RUNNING HEAD: POSTSECONDARY EDUCATION OF STUDENTS WITH AUTISM

after high school. A report from the National Longitudinal Transition Study-2 (NLTS2) (NCSER 2011-3005). Menro Park, CA: SRI International.

Qualifications and Curriculum Authority (QCA) (July, 2004). New sector and subject categories: Setting out a common approach. London: QCA.

Reichrath, E. (2013). Monitor Report 1: The GOLD project. Retrieved from the Web 17/07/2014 toetsenmetenweten.nl/data/.../Monitor-report-1-June-2013GOLD.pdf

Roth, L. (2013). Autism Spectrum Disorder Briefing Paper No 5/2013. NSW Parliamentary Research Service. Retrieved from the Web 29/01/2016, from http://www.parliament.nsw.gov.au/Prod/parlment/publications.nsf/0/B21423 91F94516FECA257B78001FB961/\$File/Autism Spectrum Disorder.briefing paper.pdf

Shattuck, P.T., Narendorf, S.C., Cooper, B., Sterzing, P.R., Wagner, M., and Taylor, J.L. (2012). Postsecondary education and employment among youth with an autism spectrum disorder. Pediatrics, 129, 1042-1049. 10.1542/peds.2011-2864

Stewart, S. (2008). I Exist: The message from adults with autism in Northern Ireland. Belfast: The National Autistic Society. Retrieved from the Web 17/07/2014 www.autism.org.uk/ /media/NAS/Documents/Extranet/Autismlibrary/Magazines-articles-and-reports/Reports/Our-reports/I\%20Exist\%20\%20the $\% 20$ message $\% 20$ from $\% 20$ adults $\% 20$ with\%20autism $\% 20$ in $\% 20$ Northe rn\%20Ireland.ashx

Treehouse (2009). Disobedience or disability? The exclusion of children with autism from education. Report 3. London: Treehouse. 
RUNNING HEAD: POSTSECONDARY EDUCATION OF STUDENTS WITH AUTISM

UK Statistics Authority (January 2009). Code of Practice for Official Statistics. Edition 1.0. London: UK Statistics Authority. Retrieved from the Web 17/07/2014 www.google.co.uk/url?sa=t\&rct=j\&q=\&esrc=s\&frm=1\&source=web\&cd=1\&ved= 0CCoQFjAA\&url=http\%3A\%2F\%2Fwww.statisticsauthority.gov.uk\%2Fassessme nt\%2Fcode-of-practice $\% 2$ Fcode-of-practice-for-officialstatistics.pdf\&ei=g834UtbPGaOt7QbS34GgCg\&usg=AFQjCNHC801PYGPFNcq8L mr-b0xe490z1A\&bvm=bv.60983673,d.bGQ

United Nations Convention on the Rights of Persons with Disabilities (UNCRPD) (2006). Retrieved from the Web 21/01/2013. www.un.org/esa/socdev/enable/rights/convtexte.htm.

Welsh Government (2012) Further Education, Work-based Learning and Community Learning in Wales Statistics, 2010/11. Cardiff: Welsh Government.

Welsh Government (2013) Further Education, Work-based Learning and Community Learning in Wales Statistics, 2011/12. Cardiff: Welsh Government.

White, S.W., Ollendick, T.H., Bray, B.C. (2011). College students on the autism spectrum: Prevalence and associated problems. Autism, 15, 683-701. $10.1177 / 1362361310393363$

World Health Organisation (2014). International Statistical Classification of Diseases and Related Health Problems 10th Revision (ICD-10)-2014: Disorders of psychological development. Retrieved from http://apps.who.int/classifications/icd10/browse/2014/en\#/F84.5 
Figure 1: Qualifications of school leavers

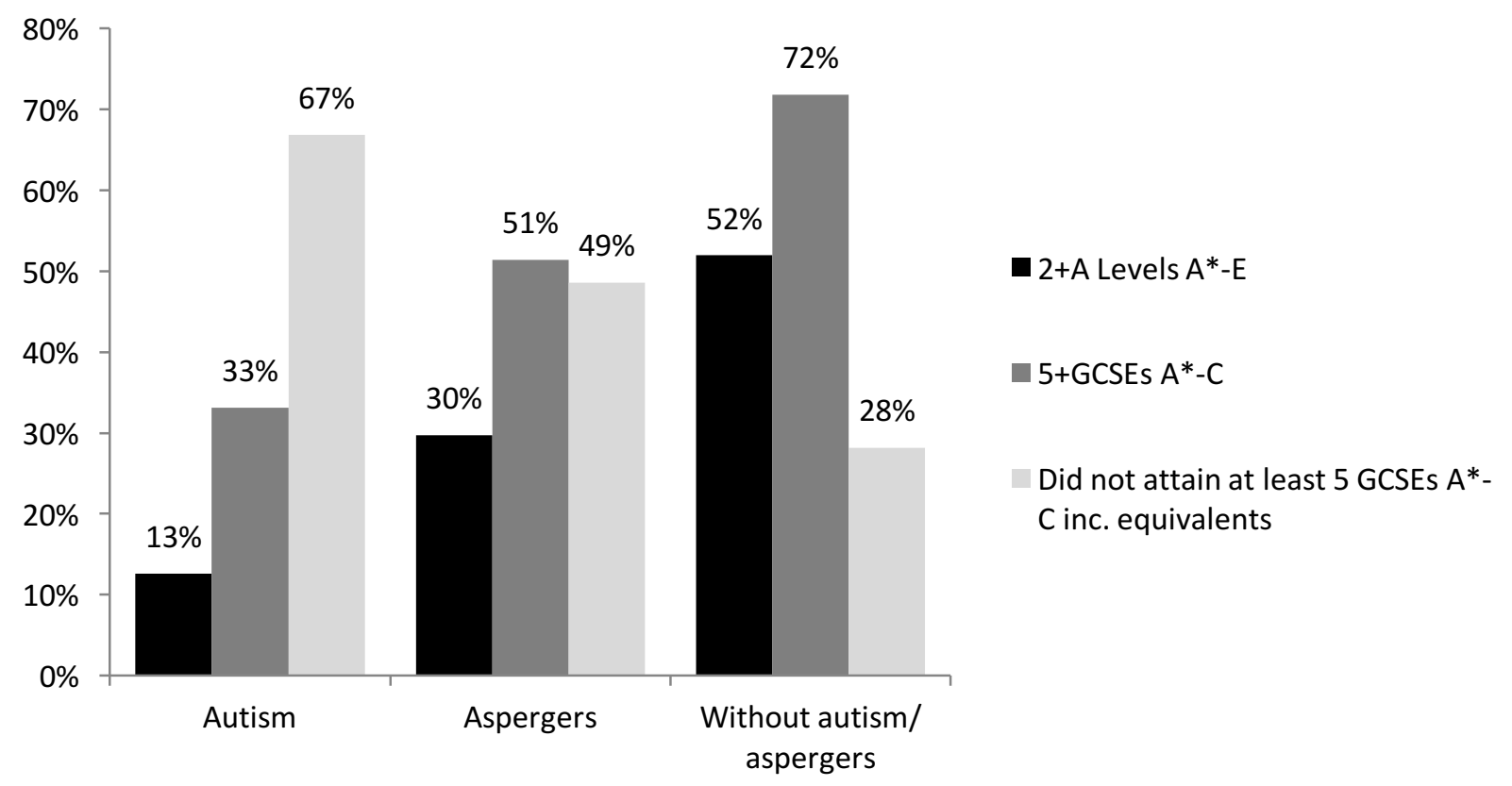

Note: '5+ GCSEs A*-C' and 'Did not attain at least 5 GCSEs A*-C inc' add to $100 \%$. '2+ A levels A*-E is a subset of '5+ GCSEs A*-C'. 
Figure 2: Destinations of school leavers

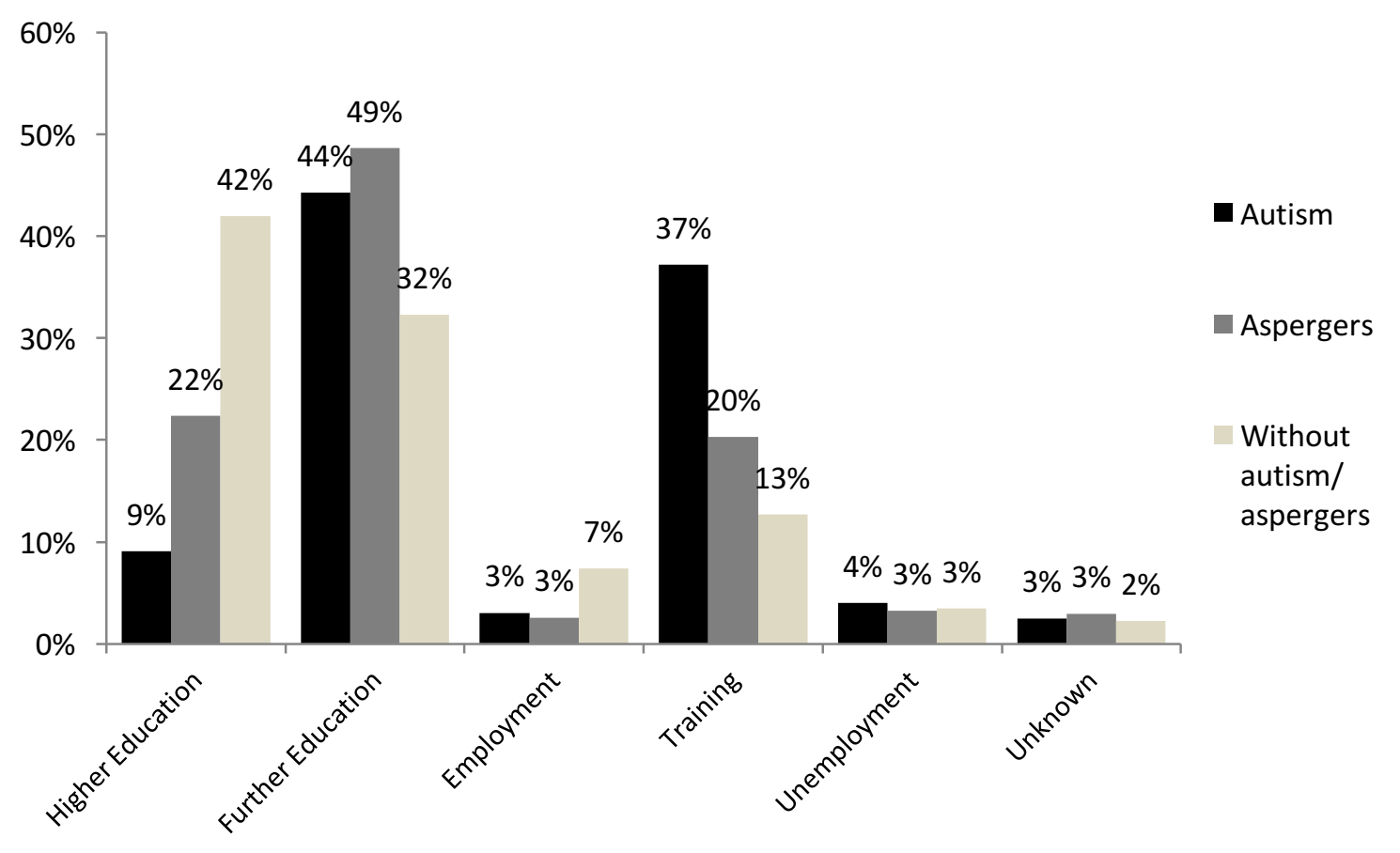

Figure 3: Proportion of Further Education college enrolments made by students with ASD in United Kingdom*

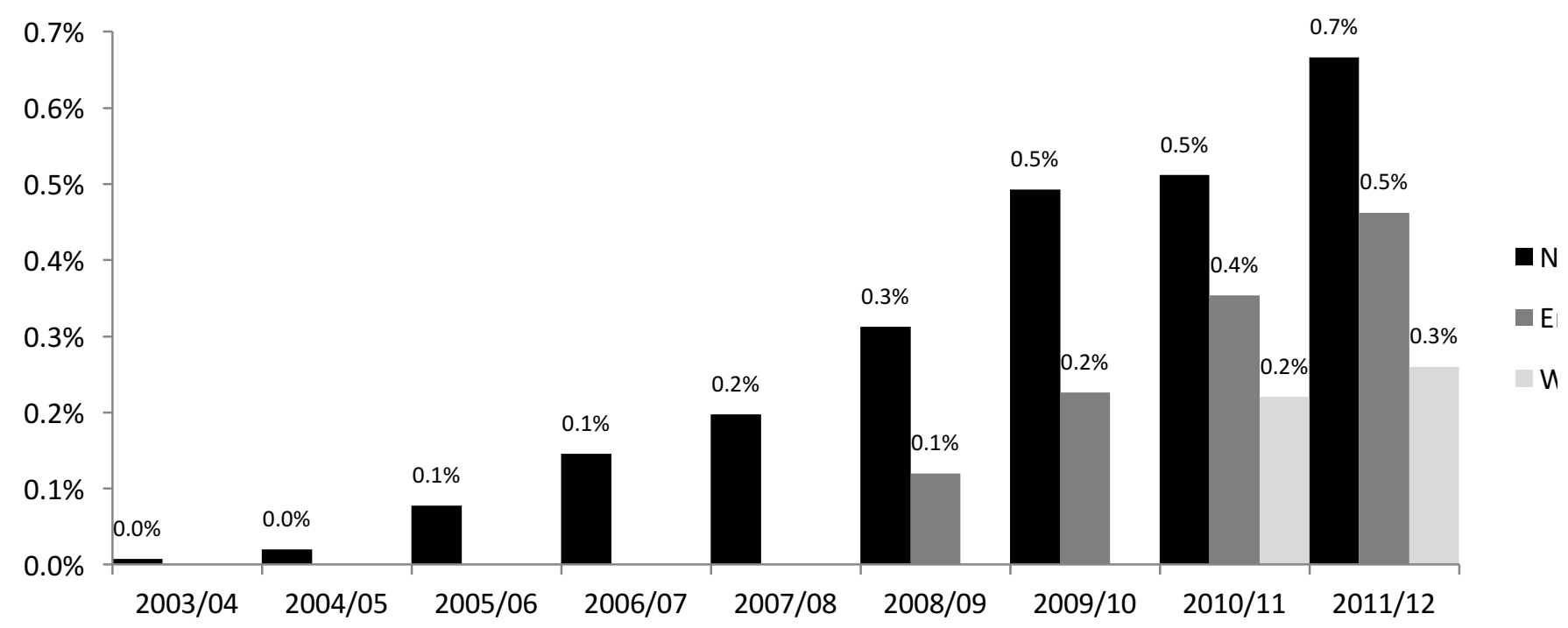

* no data available for Scotland 
Figure 4: Proportion of Further Education college enrolments made by students with ASD according to level of study in $2011 / 12$.

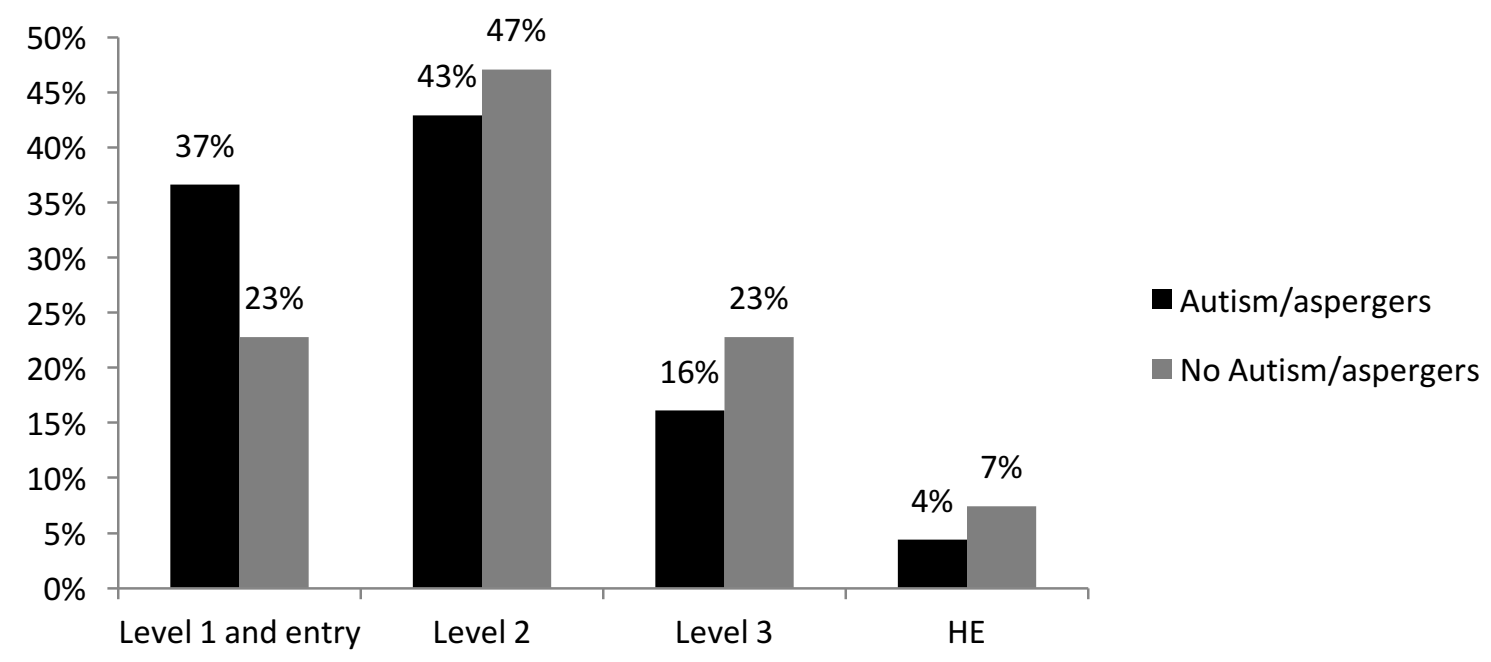

Note. HE $=$ Higher Education and is equivalent to National Qualifications Framework Level 4 and above

Figure 5: Proportion of Further Education college enrolments made by students with ASD according to mode of attendance in 2011/12

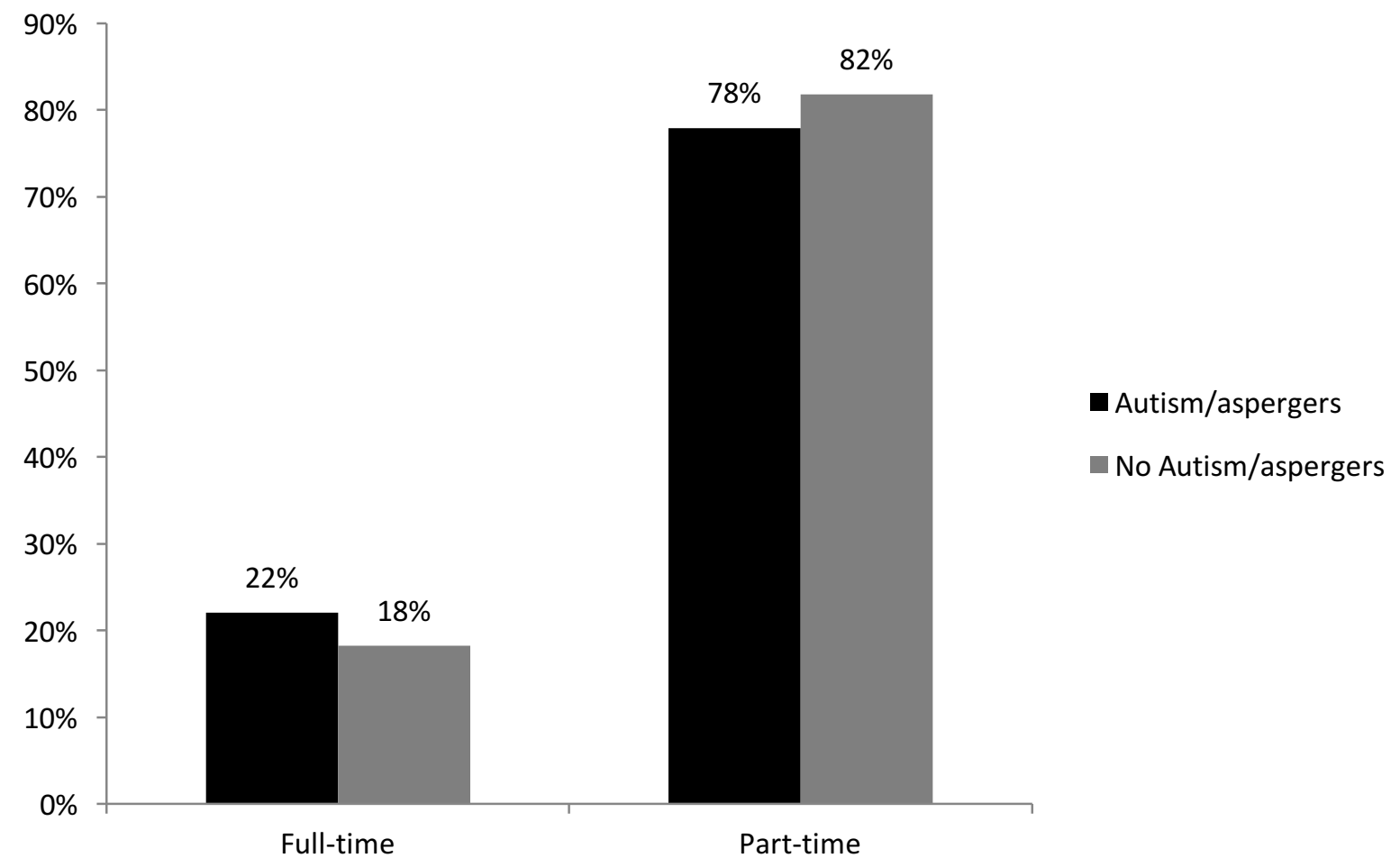


Figure 6: Proportion of Further Education college enrolments of students with ASD and students without ASD according to study subject

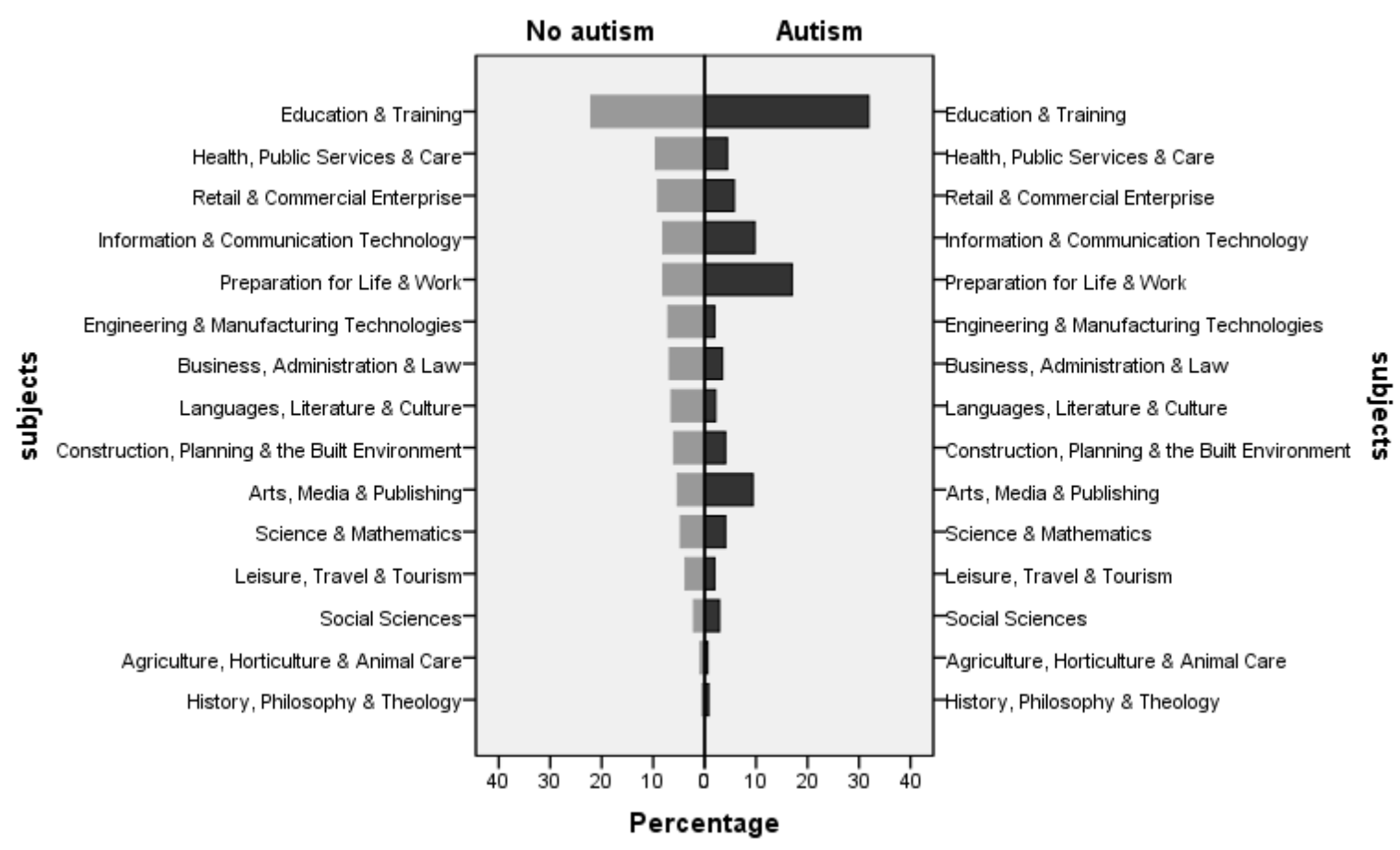

Figure 7: Final year retention rates for students with ASD and students without ASD in Further Education colleges

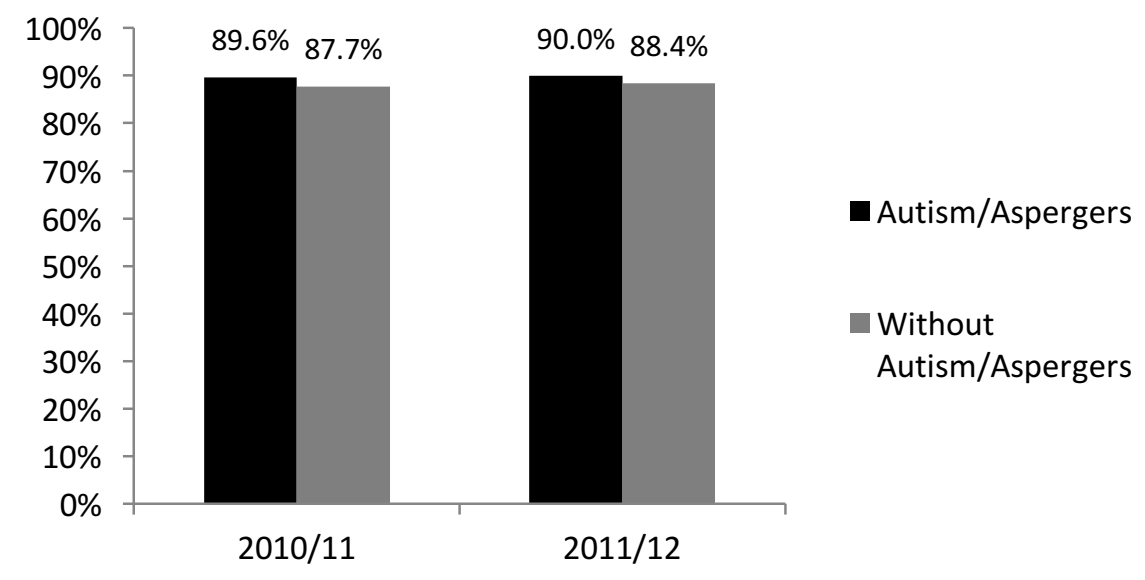


Figure 8: Final year achievement rates for students with ASD and students without ASD in Further Education colleges

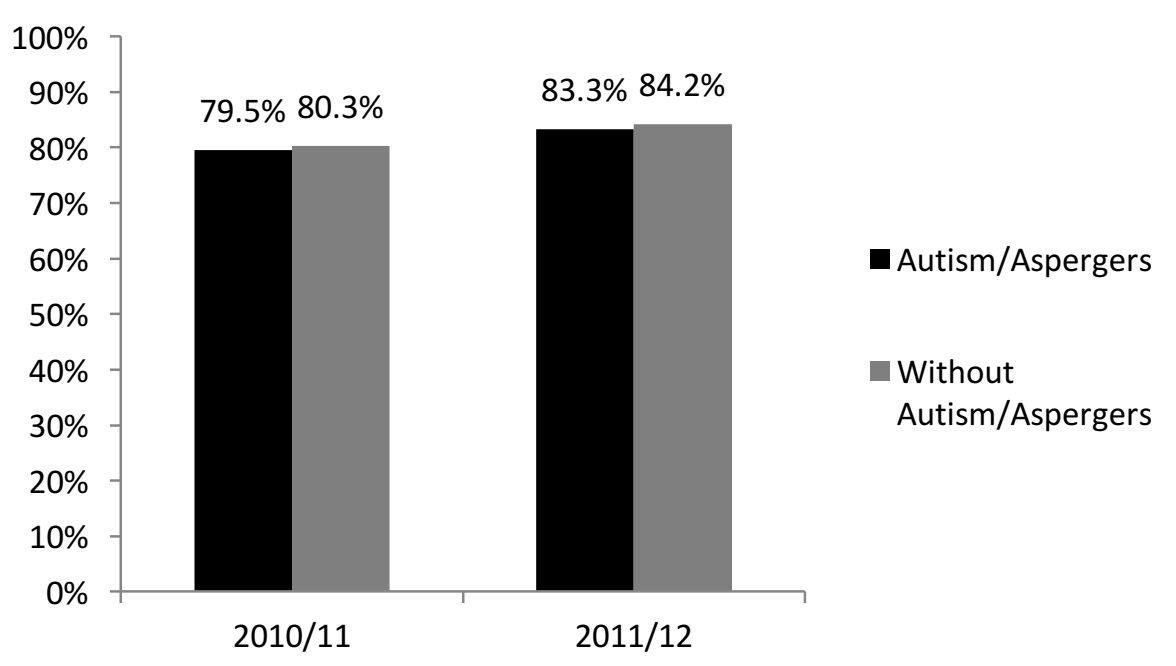

Figure 9: Percentage of students with ASD within Higher Education Institution enrolments in Northern Ireland and Great Britain.

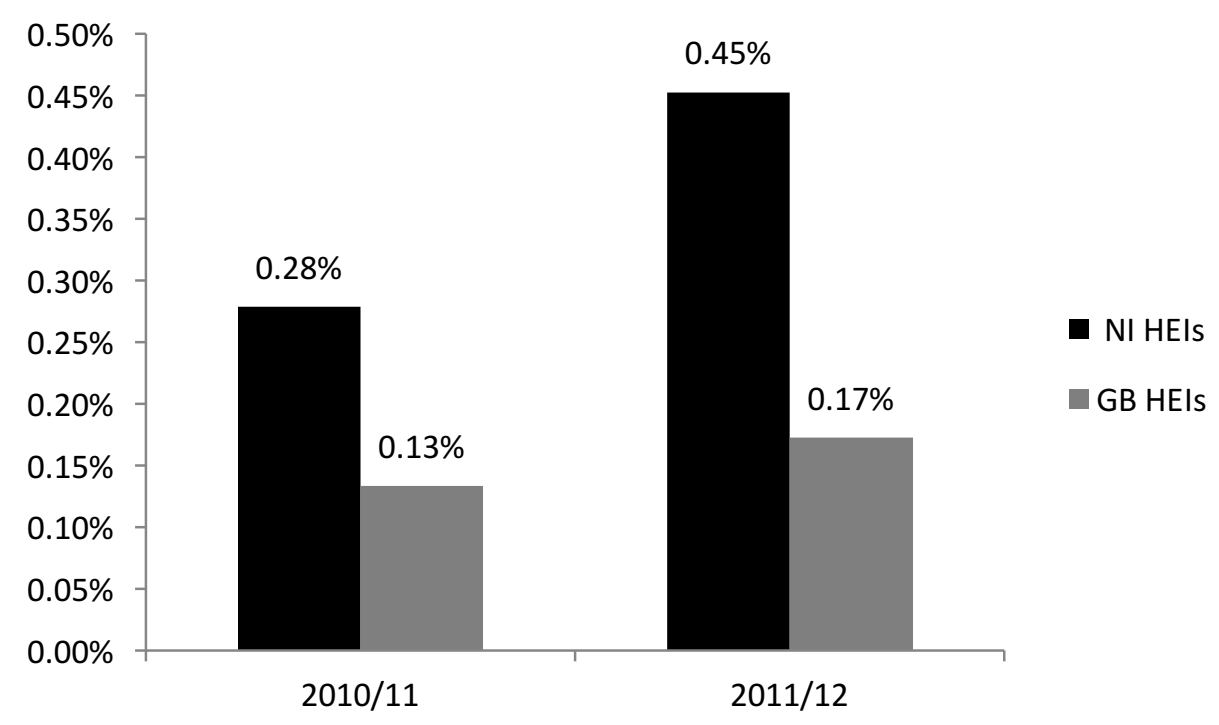


Figure 10: Country of origin of students with ASD and students without ASD enrolments at Higher Education Institutions in Northern Ireland

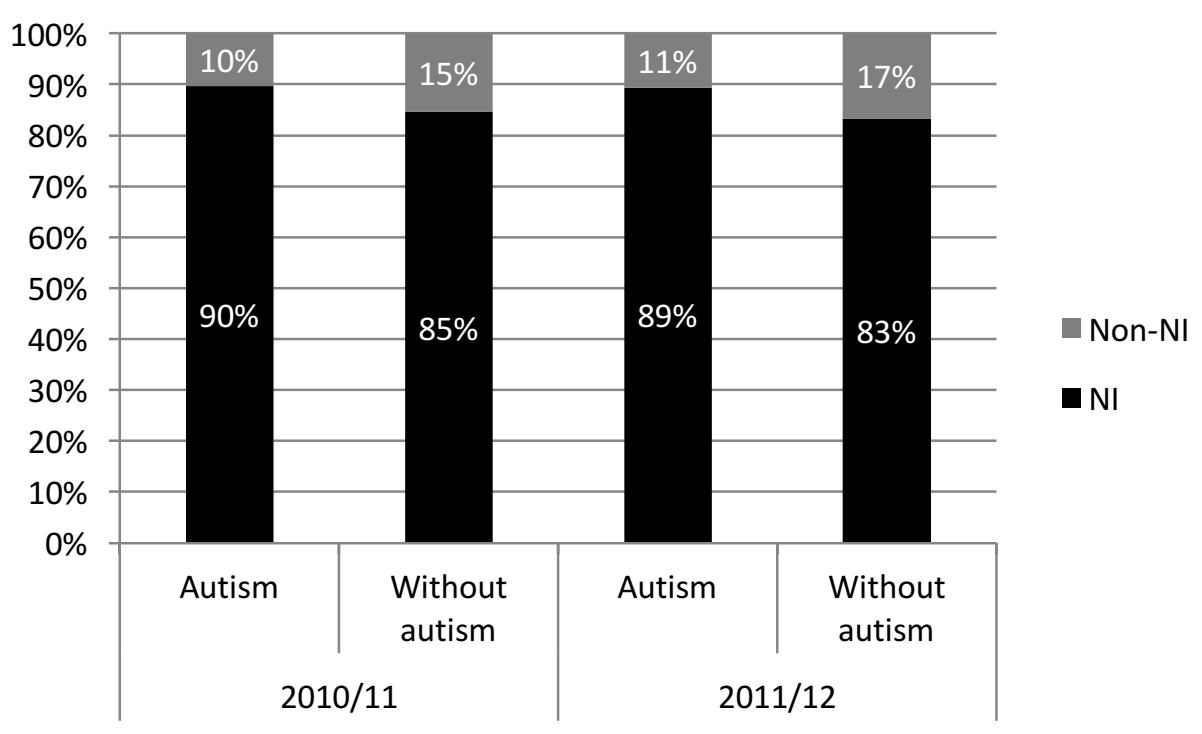

Figure 11: Country of Higher Education Institution selected by students with ASD and students without ASD from NI

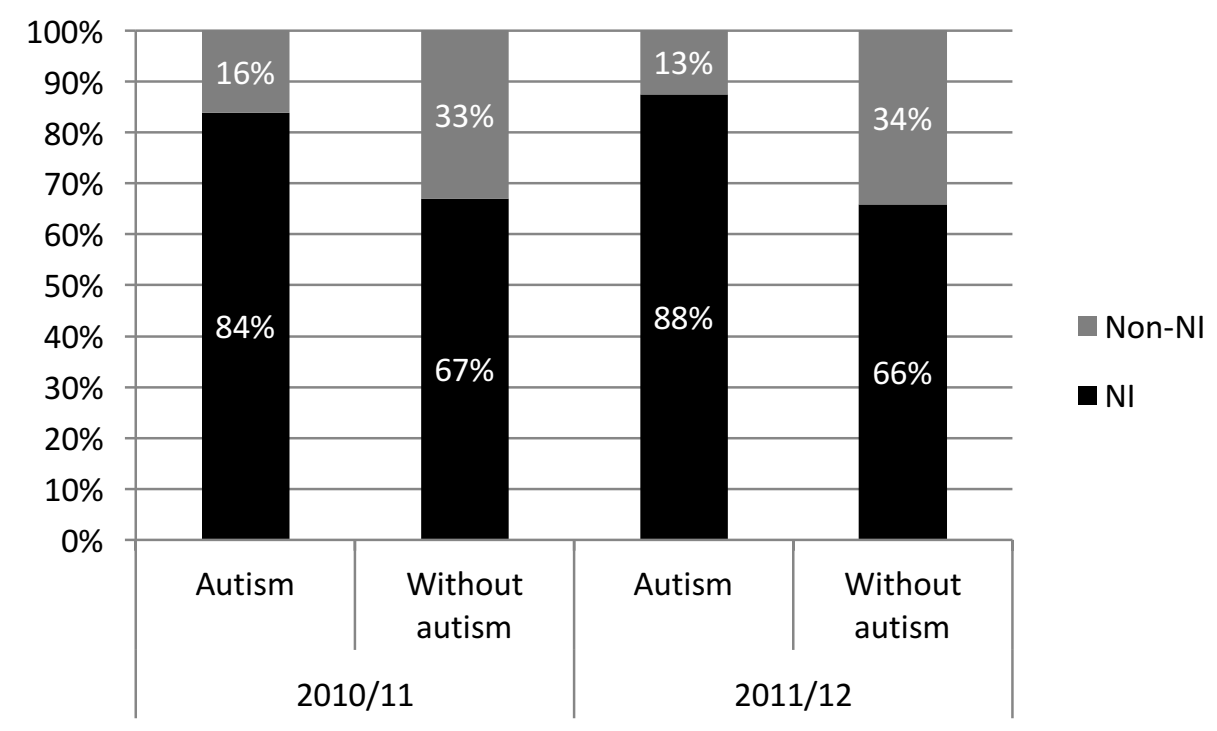


Figure 12: Higher Education Institution enrolments by subject area for students with ASD and students without ASD in NI

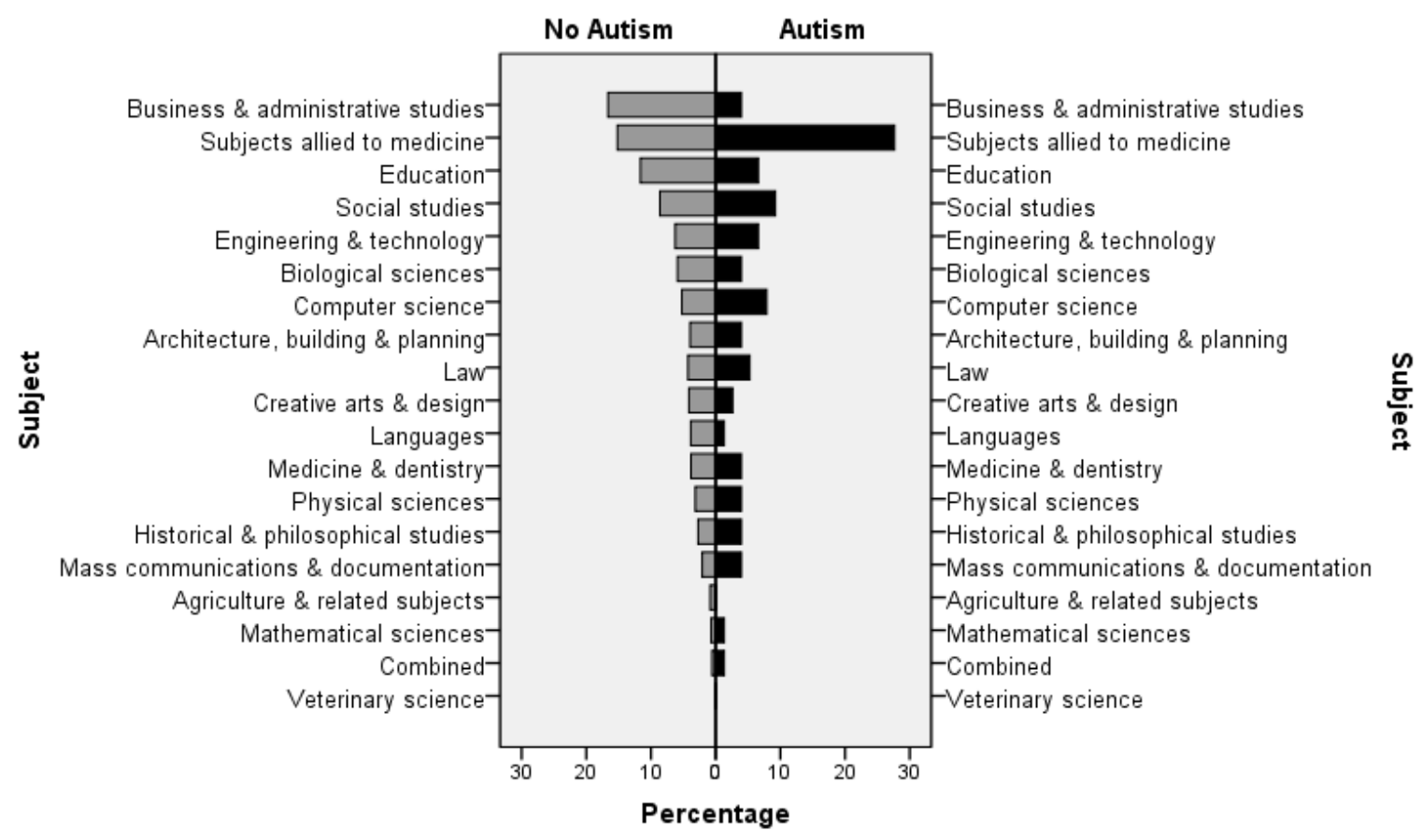


Figure 13: Higher Education Institution enrolments by subject area for students with ASD and students without ASD in GB

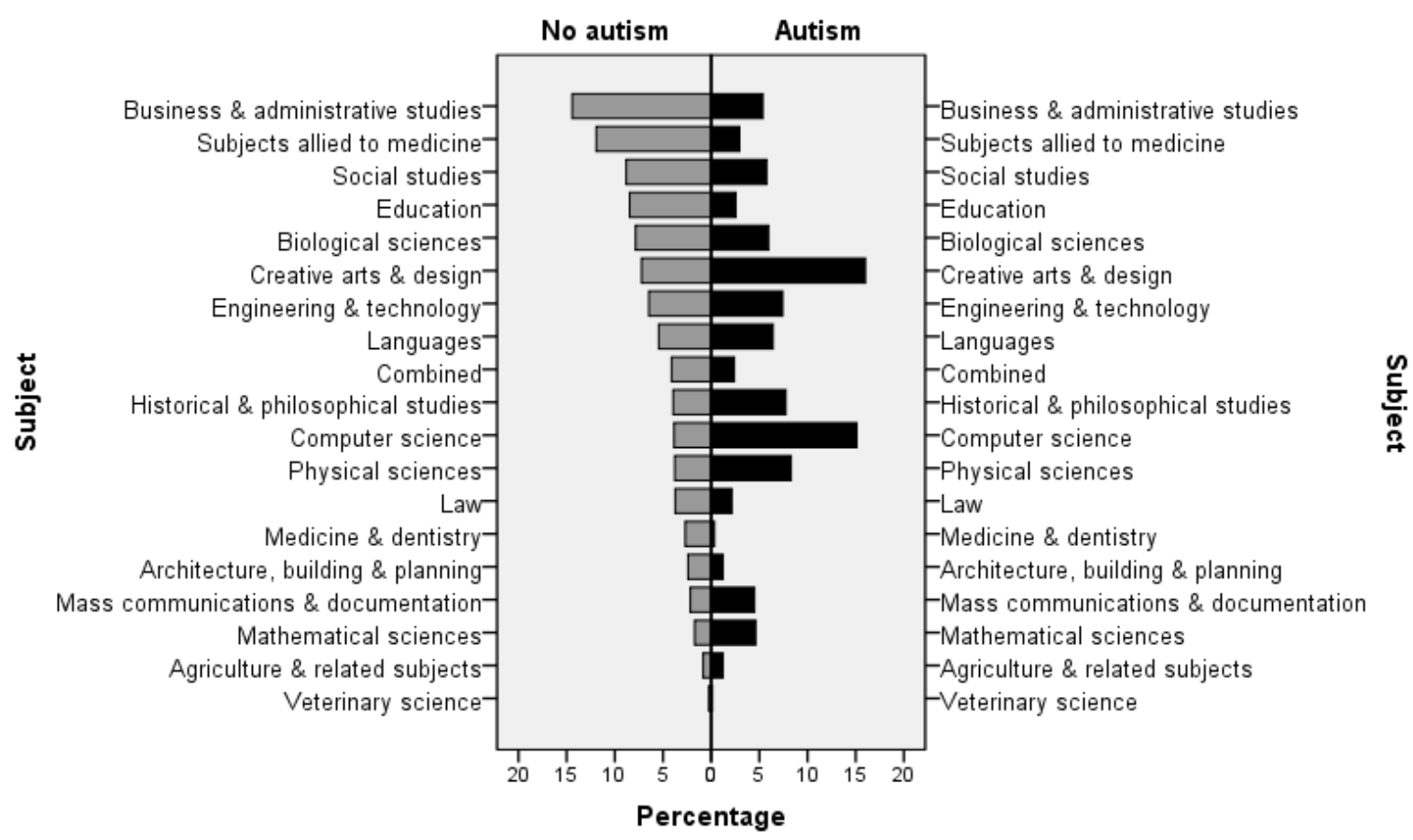

